http://dx.doi.org/10.4314/gil.v5i1.3

\title{
A PRAGMA-STYLO-SEMANTIC ANALYSIS OF PROVERBS 26, VERSES 4
} AND 5

\author{
Joseph Omoniyi Friday-Otun
}

\begin{abstract}
Although, the majority view of scholars supports the position that the Proverbs of Solomon are influenced by the Instructions of Amenemope of ancient Egypt, the book of Proverbs is believed by Christians to be one of the poetic books of the Bible known for words of wisdom. The first twelve verses of chapter twenty-six are devoted to the fool. With the possibility of being drawn into conversation with the fool, verses four and five become instructive to the wise. The purpose of this study is to demonstrate that a pragma-stylo-semantic interpretation of these verses cancels out the overt contradiction. The semantic and pragmatic presuppositions, as well as the stylistic features of the verses are unravelled to arrive at the underlying connections that unify their interpretations. Also, time-lapse or gap is considered fundamental and analysed using the concept of "appropriateness" in terms of possible compliance with the instructions in the two verses by a single agent. The paper proposes a schematic diagram supportive of the concept of "appropriateness". The various levels of linguistic, situational, psychological, sociological and cosmological contexts of the text have been examined with the illocutionary forces of the text investigated. These are done with the purpose of arriving at a "global" or "total" meaning. At the end, the analysis indicates a non-contradictory, contextdetermined phenomenon.
\end{abstract}

Key words: Pragmatics, Stylistics, Semantics, The book of Proverbs, Amenemope, Contexts

\section{Introduction}

Proverbs, Chapter Twenty-Six:

V.4: Answer not a fool according to his folly, lest thou also be like him.

V.5: Answer a fool according to his folly, lest he be wise in his own conceit. -King James Authorised Version

It is a general assumption that verses four and five of proverbs twenty-six, are 
overtly contradictory. Moreover, the verses are structured sequentially in that chapter with the negative verse (verse 4) preceding the affirmative one (verse 5). Our aim in this paper is to explicate the various contexts through which the verses can be interpreted with the purpose of resolving the assumed contradiction from the pragmatic, semantic and stylistic viewpoints. Bible scholars and users need not be in a dilemma on what meaning to assign, while tackling the verses in totality. The verses in their order represent two counsels handed down by the same author with "four" negating "five" directly. House and Durham (1992) refer to the two verses as an example of a "more confusing combination of oppositions" when taken superficially.

Our text, though an extraction from chapter 26 , is significant because the counsels thereby are of relevance to human beings at large, regardless of religion, culture, colour and status. Aside from personal moral enrichment to be gained from a study of this type, more intellectual insights will accrue, thus enhancing the frontiers of pragmatic, semantic and stylistic theories.

Almost at a glance, the semantic inadequacy posed by an attempt at resolving the contradiction in those verses becomes obvious. Yet, whenever facts about meaning are to be described, the tendency is to reach for semantics. The scope of structural semantics had set a ceiling for it. For instance, semantic theories such as meaning postulates and componential analysis are word-based (Adegbija 1985), implying a sentence-level interpretation, which though relevant to this study, proves to be grossly inadequate for the full interpretation of the text.

To capture the totality of the dimensions of meaning that will form our focus in this work, pragmatics, which according to Levin (1997: 48), "is an aspect to which are reckoned all those mechanisms that relate the language to its context of use, its audience, and the non-linguistic setting", is crucial. Also of importance to the study is stylistics, which aims at analysing language habits with the purpose of identifying those features which are restricted to certain individuals' use of language in certain kind of contexts. Furthermore, the "appropriateness" concept, which relates the suitability of an individual or group of persons to complying with instructions, pieces of advice and warnings in certain contexts, is significant; and the speech acts classification theory, that taxonomises the language functions in a given speech or a text, is essential (Allan 1986; Adegbija 1988; Van Djik 1992; Ajileye and Ajileye 1997; Lawal 2012; Adeniji and Osunbade 2014).

\section{Linguistics, Pragmatics, Stylistics and the Bible}


The Bible is the Christian Holy Book containing 66 sacred Books with 39 in the Old Testament and 27 in the New Testament. The Bible may be used for both spiritual and literary purposes. As the written text for divine instructions- warnings, admonitions, commands, etc., it is rendered in chapters and verses. As a sacred literature, it is written in human language with impetus generated for its linguistic and literary studies (Adeyanju 1998). The Bible, because of its spiritual, moral and socio-cultural relevance, has undergone translations into more languages than any other known sacred book, with the English translation having several versions. The Authorised King James Version is the choice for this research because it is referred to as the most faithful to the original Greek or Aramaic text (Babatunde 1988). The Bible can be examined linguistically, e.g., on the levels of phonology, morphology, semantics and syntax, while its literary and sociolinguistic values make it a fertile ground for studies in pragmatics, stylistics and discourse analysis. However, only the pragmatic, semantic and stylistic features of the text are of relevance to this study.

\section{Pragmatics}

Leech and Thomas (1990) describe linguistic pragmatics by differentiating it from semantics, and define pragmatics as accounting for the meaning which utterances have for their users and interpreters. Semantics, according to them, has to do with meaning as a dyadic relation - the relation between a form and its meaning, whereas pragmatics has to do with meaning as a triadic relation - the relation that holds among the form, meaning and context. In his own opinion, Van Dijk (1992) states pointedly that the actual context is defined by the period of time and the place where the common activities of speaker and hearer are realised, and which satisfy the properties of 'here' and 'now' logically, physically and cognitively. Pragmaticians agree that pragmatic study is context - provoked. Contextual exploration is therefore successful if the contextual factors of any utterance or text are well explicated.

Linguists in pragmatics have postulated theories aimed at accounting for all possible interpretations of meanings in context. Concepts such as speech acts, presupposition, implicature, mutual contextual belief (MCBs), co-operative principle (CP), face maintenance (FM), etc., emerged to explore some possible constraints in allocating meanings to utterances.

Early speech act theories were first traced to philosophers of language (e.g. J.L. Austin, I.R. Searle and H.P. Grice) who were non-linguists, but whose works have been 
sources of inspiration to linguists. According to Austin (1962), an utterance could constitute three kinds of act. The first act - locutionary act or locution - is the act of making some utterances, which may be referred to as a linguistic act. The second act illocutionary act - is the act performed by virtue of the locution, such as urging, requesting, ordering, greetings, etc. The last act identified by Austin, called perlocutionary act, is the effect that a particular utterance has on the speaker or listener. He further opines that the middle ground act - illocutionary - can be accomplished through a performative sentence. He classifies illocutionary acts into five classes, thus: Verdictives, Exercitives, Commissives, Behabitives and Expositives. Searle (1974) also comes up with five groupings in his bid to correct what he refers to as overlapping in Austin's classifications. His own classes are Assertives, Directives, Commissives, Expressives and Declaratives. He postulates that two rules, regulative and constitutive, govern conversation in the use of a language.

Grice's (1975) major contribution to speech acts is the popular cooperative principle $(\mathrm{CP})$ theory which refers to unconscious interactional agreement that subsists during conversations. He assumes that four maxims are constituted during conversation. They are the maxims of Quantity, Quality, Relation and Manner. He also proposes the concept of implicature which centres on context, the purview of pragmatics. This concept distinguishes what is implied from what is overt. For instance, "She finished the food but was still hungry" implies that she was not expected to be hungry after finishing the food.

In the 1980s, the study of presupposition assumed a popular dimension. This concept concerns the factors, whose truth a speaker assumes as part of the background issues germane to the conversation. For example, "I know that, University of Ilorin has a crop of young professors" presupposes that University of Ilorin as an institution exists.

The concept of mutual contextual beliefs (MCBs) postulated by Bach and Harnish (1979), makes the speaker's intention and listener's inference its main focus. For a speech act to be performed, the inference drawn from the speaker's intention is paramount. In other words, certain words are put together by the listener before he/she can understand the speaker's intention (Lawal, Ajayi and Raji 1997).

Adegbija (1982) also proposes the notion of pragmasociolinguistics in analysing the context of an utterance. He argues that the global context of an utterance is constituted by both pragmatic and sociolinguistic contexts. Adegbija postulates that pragmasociolinguistic competence calls for the historical, personal, environmental, sociocultural, and linguistic features of all factors that relate to the contexts in which a 
particular conversation occurred. While decoding the meaning of the utterance, "My friend, where is Anini?" uttered by a former Nigerian President, General Ibrahim Badamosi Babangida, to his then Inspector General of Police, Adegbija describes three layers of meaning - primary, secondary and tertiary. At the primary level, according to him, meaning is assigned to linguistic elements through the device of semantic presupposition. At the secondary layer, meaning, occasioned by metaphors, insinuations, idioms, to mention a few, yield indirect speech acts. The third level, referred to as the master speech act, is where a total or global meaning is postulated using pragmatic presupposition. At the level of the indirect speech act, interpretation of meaning goes beyond assigning meaning to linguistic elements alone. For example, $\mathrm{He}$ beats a hell out of him is an utterance whose interpretation can be sought at the higher level of decoding the meaning of the metaphor "hell" and relating it to "out of him" to yield the meaning He beats him mercilessly. Adegbija further submits that, at the tertiary level, interpretation is based on the totality of the contextually relevant pragmatic elements including the speaker, hearer and his/her relationship to speaker, the history and context of the utterance, the socio-cultural and political context of the society and other assumptions of the utterance (Adegbija 1982, 1985, 1988).

Furthermore, Lawal (2012) introduces the notions of "contexts" and "competences" while stressing the importance of speech acts in a pragmatic approach of stylistic analysis. According to him, a description of the background structure of contexts and competencies which language users reactivate to interpret speech acts along with presupposition and implicature, is core in pragmatic analysis. His model has four major aspects or columns, vertically represented as contexts, competencies, background information and speech acts. The first two columns, which are symmetrically related, have behind them the one-layer surface structure, (Linguistic), and the five-layer background structure (Situational, Psychological, Social, Sociological and Cosmological) contexts and competencies. According to the model, the background information of an utterance (the third aspect, or column in the diagram) determines the presuppositions, implicature and the MCBs through which inferences are drawn by the listeners to produce speech acts. The mappings of the model are presented on the next page: 


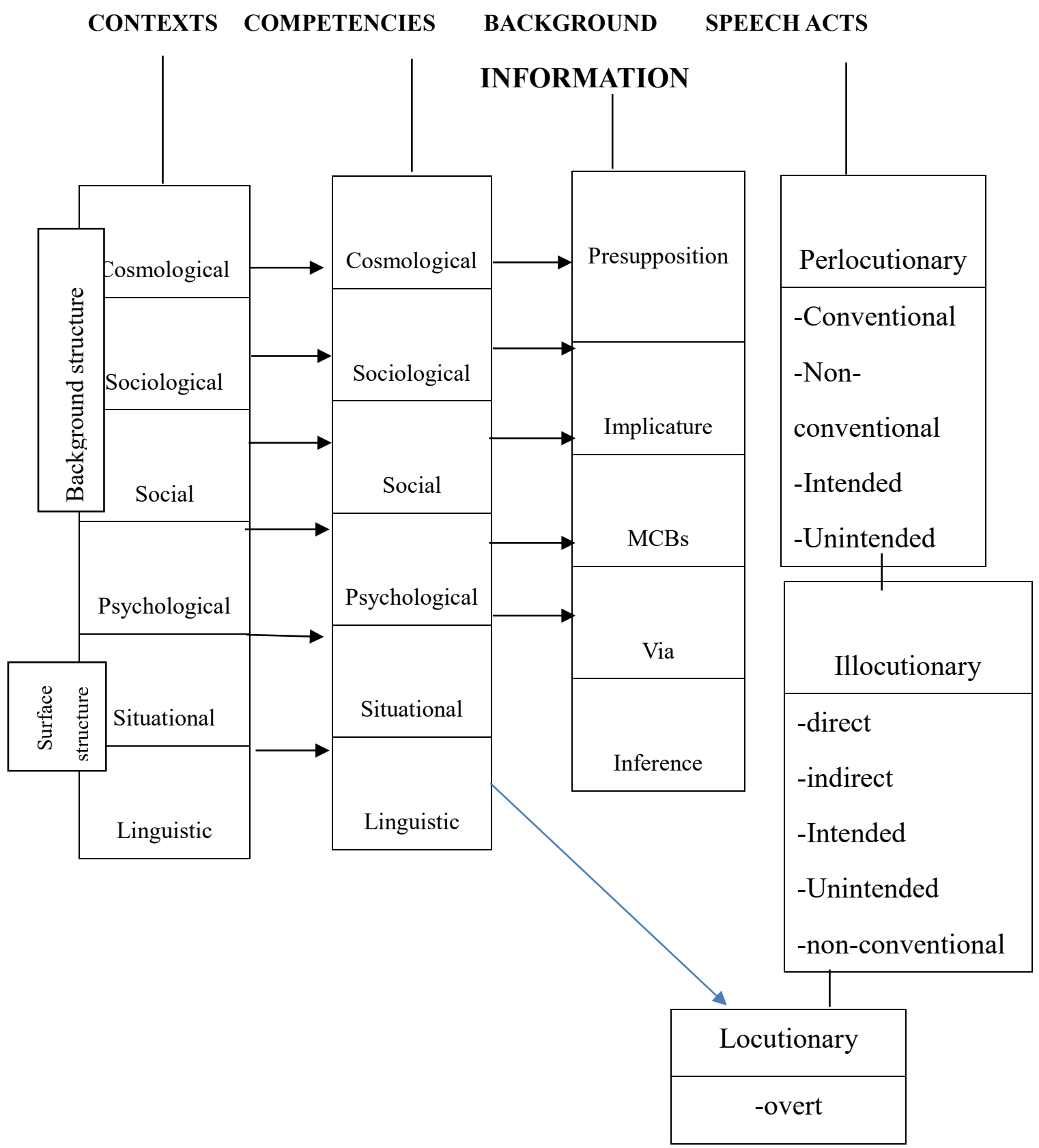

Fig 1: Lawal's Aspect of a Pragmatic Theory

From the above model, two underlying structures - "Surface Structure" and "Background Structure" which are made of six levels are identified. The first level 
(linguistic), on the first hand, constitute the surface structure, under whose domain we have the phonological, lexical, semantic and syntactic features, as the basic linguistic level at which utterances are produced and perceived. On the other hand, the background structure consists of five layers which are situational, psychological, social, sociological and cosmological. All the levels (six of them) further bifurcate into "contexts" and "competences" symmetrically. In other words, each layer under "contexts" (the first column) corresponds to that of "competencies" (the second column).

The level after the linguistic layer, the situational context and competence, refers to the topic of discourse and the factors of the physical events including, concrete objects, persons and location. In this model, the psychological context and competence, the third layer, is described as the background of the mood, attitudes, and personal beliefs of the language user. The fourth level, "social", indicates the interpersonal relations among interlocutors. The next level, "sociological", relates to the sociocultural, and historical settings that characterise the use of an utterance, while the sixth and the highest level, "cosmological", depicts the user's world-view, implying references to the world or aspects of it, and to certain universally established facts.

As earlier said, the background information (the third column), according to this theory, involves the imports of presupposition, implicature, politeness formula, MCBs and $\mathrm{CP}$, which determine the inference that a listener can draw from the speaker's intention. In addition, the model postulates that the contexts, competencies and the background information constrain the functions that utterances (or texts when written) perform. Here, the fourth aspect or the fourth column "speech acts", constitutes three layers of functions performed by speeches - locution, illocution and perlocution.

On the classification of illocutions, Allan (1986), submits that every utterance possesses both "Direct" and "Indirect" speech acts simultaneously. According to her, the sentence type identified in the utterance represents the "Direct" speech act, while the functions performed by the utterance such as, greetings, promising, informing and so on, are the "Indirect" speech acts. For instance, the statement I'm hungry which is a Direct act of "stating" can also perform an Indirect act of requesting the food vendor to serve the speaker. Allan's speech act approach is important to this study because the model is very useful in describing a short text such as the datum of this paper.

Van Dijk (1992), in his own postulation, sees context as a sequence of worldstates which do not remain identical in time but change. He describes context as a course of events which has initial state, intermediary state and a final state. Referring to actual context as a sub-set of possible contexts, Van Dijk opines that the actual context is defined by the period of time and the place where the common activities of speaker and 
hearer are realised, and which satisfy the properties of "here" and "now" logically, physically and cognitively. In relation to change, he postulates the concept of appropriateness and stresses that pragmatics must formulate the conditions determining when certain realisations are appropriate and when they are not. According to him, the actual context subsists within the act of communication and yields to the condition of appropriateness, while possible contexts are realisable possibilities within the act of language.

Van Dijk's notion of appropriateness in contextual analysis is also crucial to this study because the distinction between actual and possible contexts will enhance and unify the interpretations of several utterances that may appear contradictory. For instance, an utterance which is appropriate in context A may be irrelevant in context B. Yet, contexts A and B are possible contexts in the act of language. This brings us to the intrinsic elasticity or multiplicity in the interpretation of utterance meaning.

From the foregoing, it is obvious that the goal of reconciling the overtly contradictory verses cannot be achieved through a single approach, but by a combination of several approaches. Hence, the stylistic approach of Halliday (1966); the speech acts classification of Allan (1986); the notions of semantic and pragmatic presuppositions of Adegbija (1988); the appropriateness concept of Van Dijk (1992); and the "Aspects of a Pragmatic Theory" of Lawal (2012), will all be deployed as found appropriate.

\section{Textual Analysis}

Proverbs 26: 4-5 (Authorised King James Version)

Verse 4a. Answer not a fool according to his folly, b. lest thou also be like him

Verse 5a. Answer a fool according to his folly, b. lest he be wise in his own conceit.

\section{The Linguistic Contexts of the Text}

The linguistic context here refers to the lexical, semantic and grammatical features of the text. The author relies on the discretion of the readers to discern the two different ways of heeding the advice. The pattern of language employed in the text reflects a type of diction structured to move the reader from an advisory imperative structure of restraint to that of persuasion without blotting out the goals of 
communication.

At the grammatical level, our text is made up of two sentences with each performing an imperative function. The Negation phrase of the first part of Verse 4, "Answer not" reflects a Middle English (ME) usage. The Current English (CE) version has it as "Do not answer". Verse 4 has undergone a syntactic process of "NOT" insertion, typical of the kind allowed in poetry.

At this juncture, some semantic presuppositions can be postulated for the text. According to Strawson in Adegbija (1988: 28), semantic presupposition refers to the logical relations that hold between sentences. For our text, the following interpretations are possible postulations for verse 4 :

i. A fool exists

ii. A fool will talk foolishly

iii. The statement of a fool, may draw a foolish response.

iv. If the hearer responded accordingly by giving a foolish response, he/she will be like the fool.

v. Therefore, no response should be given to the fool.

vi. For Verse 5, i-iii interpretations above hold. The following is however peculiar to V5.

vii. You must respond accordingly

viii. If you don't, the fool will think he/she is wise.

ix. Your response will then dispel the fool's delusion.

The postulations above focus on Adegbija's (1988: 28) primary or semantic layer of meaning "concerning the meaning being borne by, or assigned to linguistic elements in intra-linguistic rather than extra-linguistic manner".

\section{Pragmatic Presupposition of the Text}

As earlier stated, a number of pragmatic presuppositions will be postulated in analysing our text using the approach of Adegbija (1988: 58-59). Referring to the works of Stalnaker (1974), and Lakoff (1990), respectively, Adegbija describes pragmatic presupposition as "assumptions and beliefs about the context", or "shared beliefs of background information of an utterance", or "the proposition whose truth a speaker takes for granted as part of the background of the conversation" (58). In this study, both immediate linguistic and extra-linguistic contexts, the socio-cultural milieu and the 
entire pragmatic background of the contexts of the utterance, are of importance. All these are deployed to reconcile verse 4 with verse 5 as follows:

(1) Solomon in Verse 4a instructs his son not to "answer a fool according to his folly" whereas, he, in Verse 5a instructs his son to "answer a fool according to his folly".

(2) Verse $4 \mathrm{~b}$ expresses the reason why Solomon's son should not reply to a fool according to his folly: "lest thou also be like him". In 5b, Solomon states the reason for replying to a fool according to his folly: "lest he be wise in his own conceit".

(3) Though $4 \mathrm{a}$ and $5 \mathrm{a}$ appear contradictory, $4 \mathrm{~b}$ and $5 \mathrm{~b}$ respectively give separate reasons for the apparent contradiction.

(4) It is semantically and pragmatically logical that $4 \mathrm{~b}$ and $5 \mathrm{~b}$ imply different contexts of compliance.

(5) The pragmatic competence or knowledge of the participants, as well as the understanding of the appropriateness context of the text enable the participants to discern between the time Solomon's son may look like a fool if he replies a fool, and when he should reply to a fool, so that the fool would not be wise in his/her own eyes.

(6) The text which primarily involves Solomon and his son, now stretches from Solomon, or God (when taken as God's message from Solomon) to all Bible users or believers.

(7) With different contexts established for complying with Verses 4 and 5, respectively, as in (4) above, the time-setting for heeding verse 4 is different from that of 5. It is then possible for Solomon's son, or affected participants to comply with both instructions without any confusion or conflict.

(8) The appropriateness of the responses (in either replying to a fool or not) depends on the linguistic, extra linguistic and pragmatic competence of Solomon's son or Bible believers.

(9) The addressee(s) discretions are highly challenged for a 'deep understanding of "a fool" in Bible contexts and proper discernment and appropriation of the two different reasons, i.e. verses $4 \mathrm{~b}$ and $5 \mathrm{~b}$, respectively.

(10) The summary of the whole postulations is supportive of the maxim of relevance, that "there is a time for everything under the sun" (Ecclesiastes 3:3). This includes a time to answer a fool and a time not to answer him.

\section{The Speech Act Structure of the Text}


A pragmatic exploration of an utterance, or text when written, must attempt a speech act analysis of the discourse (Van Dijk 1992; Lawal 2012; Adeniji and Osunbade 2014). As earlier said, utterances perform three acts - locution, illocution and perlocution. A locutionary act performed in order to communicate carries along with it some non-linguistic acts like warning, greetings, advising, informing, etc. These acts in turn produce effects on both the speaker and listener known as perlocutionary effects. The text has sequences of two sentences, thus:

\section{V4- Clause a. Answer not a fool according to his folly, Clause b. lest thou also be like him \\ V5- Clause a. Answer a fool according to his folly, Clause b. lest he be wise in his conceit.}

Each of the verses or sentences has two parts - (a) and (b), "lest", the interclausal discourse connector, conjoins both parts in each verse. As earlier said, this work adopts the speech act framework of Allan (1986), who classifies illocutions into "Direct" and "Indirect" speech acts. She describes a "Direct" function as the sentence form of an utterance or text, and the "Indirect" act as the illocutions expressing the speaker's intentions. In other words, the "Indirect" speech act is the illocutions like greeting, advising, informing etc., performed through the sentence types used in the expression. The sentence forms (Direct Act) are mainly declarative (statement), interrogative and imperative. Illocutionary acts of this text can be classified into "Direct" and "Indirect" acts. Each verse or sentence has two parts or clauses with each part performing a different act. Clauses 4a and 5a, respectively, perform similar "Direct" acts (sentence form) of "imperative" and similar "Indirect" acts of "advisory" functions. Clauses $4 \mathrm{~b}$ and 5b) perform "Direct" and "Indirect" acts different from those of 4a and 5a. While $4 \mathrm{~b}$ and $5 \mathrm{~b}$ perform the "Direct" act of "declarative", respectively, they, at the same time perform the "Indirect" act of "warning" individually,

A total of eight instances of speech act are found in the text:

$$
\begin{aligned}
4 \mathrm{a}-1 \text { Direct (Imperative) }+1 \text { Indirect (Advisory) } & =2 \\
4 \mathrm{~b}-1 \text { Direct (Declarative) }+1 \text { Indirect (Warning) } & =2 \\
5 \mathrm{a}-1 \text { Direct (Imperative) }+ \text { I Indirect (Advisory) } & =2 \\
5 \mathrm{~b}-1 \text { Direct (Declarative) }+1 \text { Indirect (Warning) } & =2 \\
\text { Total } & =8
\end{aligned}
$$

The speech acts or illocutions above are characterised by the "Direct" acts of Imperative 
and Declarative functions, as well as the "Indirect" illocutions of Advisory and Warning acts. Hence, Solomon employed the Direct declarative act to accomplish the "Indirect" illocutions of advising and warning his son, and subsequently Bible believers. In other words, Solomon advised and warned his son in imperative statements of two sequences with each sequence representing two different contexts of possible compliance.

\section{Stylistic Features of the Text}

In stylistics, the error of classics in linguistics lingers as it was studied during its early period from the prescriptive point of view. A shift towards descriptive stylistics emerged perhaps due to the influence the similar shift from prescriptive to descriptive linguistics had on it (Ducrot and Todorov 1972). Widowson (1975) views stylistics as the study of literary discourse from a linguistic orientation. Levin (1964) sees it as the study of the elements of semantics, phonetics, phonology and syntax that a writer uses in the production of his text. Literary stylisticians have restricted stylistics to the study of linguistic elements or variables or nuances and their degree of occurrences in literary works of art. This, according to Olajide (1997), reflects in literary texts where the writer can afford the use of flowery and seductive language to appeal to his reader's imagination. While stressing that the significance of literary texts as displaying the greatest stylistic challenges should not be missed out, Lawal (2012: 26) sees stylistics "as a branch of linguistics deriving largely from a sociolinguistic interest in the treatment of variables in entire texts, viewed as communicative events. He argues further that "language variation and the distinctiveness of features within and across texts, as occasioned by situational factors are major purview of stylistics, as an emergent field in the study of language" (Lawal 1997: 26).

In social encounters, language users deploy language to express their thoughts, beliefs, habits, experiences, moods, etc. meaningfully in diverse styles. These expressions underline the language habits allocated or assigned to certain individuals. Halliday (1966) supports the view of Widowson (1975), but adds that stylistics studies both literary and non-literary texts from a linguistic point of view. The view of Halliday (1966) is relevant to this study because stylistics can be constructed in literature, as well as in other discourses across disciplines such as religion, law, journalism, medicine, etc.

The stylistic aspect of our study involves the linguistic and literary styles the author employed to couch the text. Style is conceived here as some or all of the language variations that our datum reflects. Doubtlessly, our datum contains variations which are 
crucial to its holistic analysis. For instance, the paradigmatic sequencing style of our text is a clear deviation from the norm, in that, V4 contains a negative structure followed by an affirmative type in V5. Ordinarily, it should be the other way around, because affirmative structures should generate negative forms through a process known in syntax as NEGATIVE insertion. However, stylistics has an answer to this because the author should have chosen to deviate using a paradigm of an alternative variant that suits his purpose.

The theme of our text is situated within the background of Solomon's desire to teach his sons, even as his father, David, taught him life ethics or morals which later became generalised words of wisdom that touch on finance, marriage, family, religion, education, politics, vocation, etc. (House and Durham 1992). Furthermore, figures of classical rhetoric like scheme of balance, repetition and alliteration are employed by the author to reflect his flow of thoughts. A scheme is an artful deviation from the ordinary arrangement of words (Adeyanju 1998).

In chapter 26 ,

4a. Answer not a fool according to his folly, and

5a. Answer a fool according to his folly

reflect a scheme of balance in oppositeness. Both parts should have passed for an absolute scheme of repetition but for "not" which is in 4a. The second parts: "lest thou also be like him" and "lest he be wise in his conceit" are schemes of parallelism. The scheme of alliteration, e.g. "f" of "fool", repeated in "f" of "folly" is used in both sentences. Inter-sentential repetition is also common to both verses e.g. "Answer" is used at the beginning of each verse and "according to his folly" is repeated in both sentences, "lest" is repeated at the beginning of "b" part of each verse. The repetitions in our text, perhaps, occur for the sake of emphasis. It can be safely said that the author deployed literary and linguistic devices to vividly and emphatically convey his messages without missing out the aesthetics associated with great philosophers and orators.

\section{The Appropriateness/Possible Contexts of the Text}

The need for us to bring to the fore the underlying connections between the two verses are essential. The theory of appropriateness or context change of Van Dijk (1992), facilitates the understanding of sentence sequence that appears contradictory. The change in the contexts of realisation between verses 4 and 5 is a factor of appropriateness. Each of verses 4 and 5 represents different contexts of compliance. In 
other words, verse 4 is realised independently of verse 5 and vice versa. But both of them relate within appropriate or possible contexts in the act of language. We can assume that when it may be appropriate to heed V4, heeding V5 will be inappropriate.

However, we need to explore the possibilities of the simultaneous realisations of both verses, where it is taken for granted that Solomon's hearers may be many in different locations, the two verses can be arbitrarily and concurrently complied with. The possibility of each realisation subsists within several possibilities in different places at the same time. In other words, the realisation of each context is a factor of appropriateness on the bases of time and place.

We can propose a schematic diagram to illustrate this further:

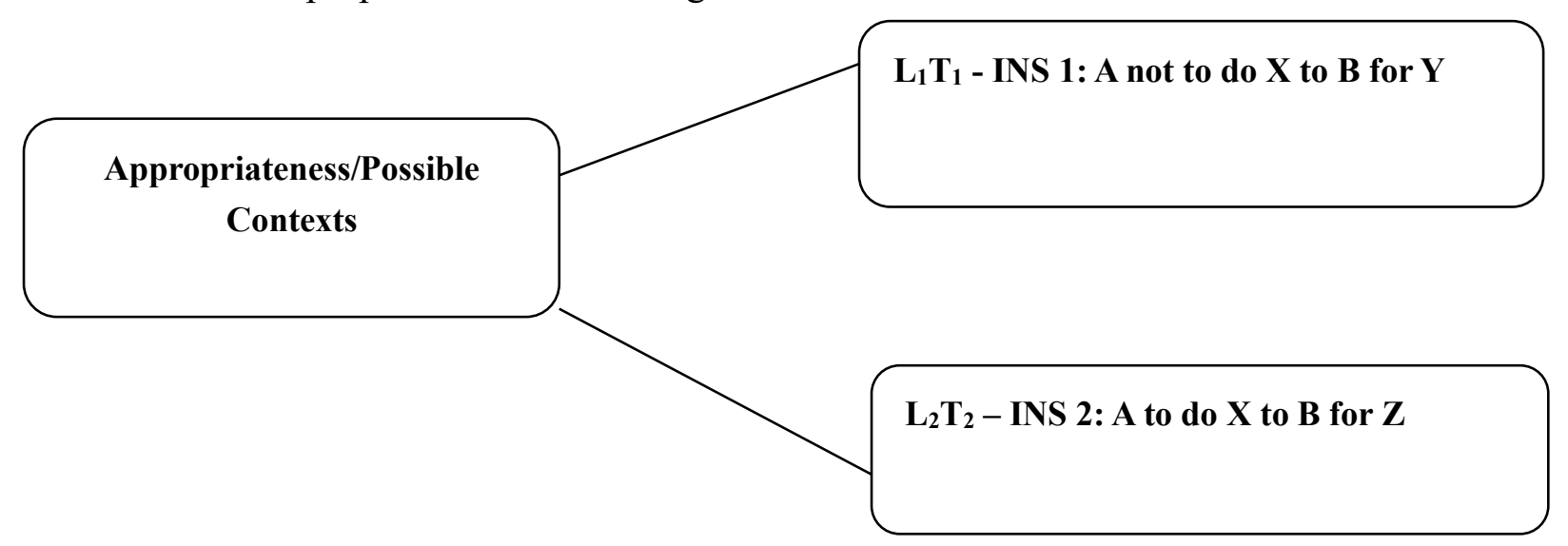

\section{Figure 2: Friday-Otun's (2016) Model, Showing Appropriate and Possible Contexts of Heeding Contradictory Instructions.}

The diagram above shows two horizontal or parallel boxes linked to another horizontal box of "Appropriateness/Possible Contexts". Each horizontal box signifies each verse of our text. At $\mathbf{L}_{1} \mathbf{T}_{1}$ (Location I, Time I) INS 1 (Instruction one: V4) is realisable. At $\mathbf{L}_{2} \mathbf{T}_{2}$ (Location 2, Time 2), INS 2 (Instruction 2: V5) is complied with. The "Appropriateness" is the link between the two boxes - the pragmatic force that unifies the two verses. INS I enjoins A (Subject Agent) not to do X (answer) B (object agent - a fool) because of Z (lest he be wise in his own conceit).

The object agent (B) can be the same or different person in both cases. The horizontal boxes are parallel because Vs 4 and 5 cannot at the same time be complied with by a single agent at the same time. However, with the appropriateness or possible contexts linking them, certain variables are possible: 
(1) When INS 1 and 2 are complied with simultaneously, the complying agents and locations will be two or more.

Or, Where complying agents and locations are more than one, INS 1 and 2 can be complied with, simultaneously:

(2) Where INS 1 and INS 2 are complied with by a single agent, times or periods of compliance will differ.

Or, When times or periods of compliance to INS 1 and 2 differ, an agent can comply with both instructions without conflict.

(3) Compliance, whether by a single or multiple agents, at the same or different times and locations, depends on the appropriateness or possible times, locations and agents. At this point, the resolution or reconciliation of the two verses is underscored.

\section{Contexts and Competencies of the Participants}

There is the need to discuss the authorship of the book of Proverbs, particularly, that of our text, before describing the contexts and competencies of the participants. The majority position of scholars contends that Proverbs are lifted from Kemetic (Egyptian) wisdom texts, and then attributed to king Solomon. However, Christians believe that the book of Proverbs is one of the poetic books of the Bible written by king Solomon and known for words of wisdom (Babatunde 1988; Adeyanju 1998; Zavada 2016). According to Pang (2014), the authorship of the book has come under academic and theological contentions by many scholars since the discovery of the Instruction of Amenemope in ancient Egypt about eighty years ago. The Instruction of Amenemope, is a literary work composed in Ancient Egypt, containing thirty chapters of advice for successful living. It was written by the scribe Amenemope, as a legacy to his son, reflecting on inner qualities, attitudes and behaviours required for a successful life in the face of ever mounting complex political, social and economic conditions (Wikipedia, 2016). Budge (1922) publishes an excerpt of the script, in a French academic work, observing that the Amenemope resembles and influences the biblical wisdom books, while adducing specific parallels between Amenemope and some texts in Proverbs, Psalms and Deuteronomy.

Capitalising on the parallels between Amenemope and Bible wisdom texts, scholars such as Erman (1924), Wilson (1951), Emerton (2001), Shupak (2005), as well as many studies of the Bible and commentaries share the view of Budge (1922) that the Amenemope collections not only resemble, but influence the biblical wisdom texts. They hinge their claims on the dating of Amenemope which is generally taken to be 
during Ramesside period, which predated the Solomonic period.

However, Ruffle (1995), Whybray (1995) and Pang (2014) doubt the relationship between Amenemope and Proverbs. For instance, Ruffle (1975) claims that the connection so casually assumed between the parallel texts are superficial, and mere coincidences that cannot survive detailed examination, while Whybray (1995) argues that only a few of the topics in the Egyptian texts can be found in Proverbs 22: 1724:22, with their sequences differing. Furthermore, Pang (2014) compares the theologies of Proverbs 22:17 - 24:22 to Amenemope and concludes that theologically, Amenemope is fully compatible with other Egyptian Wisdom Literatures, but not with Bible book of Proverbs.

From the foregoing discussion on the Egyptian Wisdom Texts and Proverbs, two points stand clear: the dating of Amenemope and the biblical parallels. However, the relevance of dating thrives on the account of the biblical parallels. This then takes us to the question of the relevance of the parallels between the Amenemope and Proverbs to our own study. This is against the backdrop that the basis for any comparison between the book of Proverbs and the Amenemope rests on the biblical parallels found in Proverbs 22:17 to Proverbs 24:22 (Ruffle 1995). Our own area of focus lies outside the texts consisting the parallels above. In other words, our text (Proverbs 26:4 and 5) does not fall within the area of contention. Hence, the aspects of the Proverbs under contention with Kemetic collections do not extend to the parts under our area of study, implying that the authorship of the text we are considering in this work could not have been influenced by Amenemope.

More significantly, the account of the Bible itself on the authorship of the Proverbs shows enough evidence of its origin. For instance, in Proverbs 1:1, "The proverbs of Solomon the son of David, king of Israel" unequivocally states the source of the book. Furthermore, the introduction to the book of Proverbs written by the author of the Amplified Bible (1987) asserts that the Hebrew title, "The proverbs of Solomon" credits the book to Solomon, who succeeded his father on the throne about 970 B.C. According to this introduction, two additional references, Proverbs 10:1, "The Proverbs of Solomon. A wise son maketh a glad father; but a foolish son is the heaviness of his mother," and Proverbs 25:1, "These are also proverbs of Solomon, which the men of Hezekiah king of Judah copied out," identify Solomon as the author of our text in particular, and of most of the proverbs in the Bible. Hence, in this paper, Solomon is regarded as the author, particularly of our data, as well as of the book of Proverbs, generally. Therefore, Solomon, his son and all Bible users are the "participants" in the contextual analysis of the text under investigation.

So far, a little has been said "pragmatically" about the participants of our texts, especially Solomon (the author). The participants" "contexts" and "competences" including the "speech acts" they performed deserve our attention. The various levels of 
the participants' "contexts", "competencies" and "speech acts" as seen in Lawal (1997) are relevant to this study. The levels are linguistic, situational, psychological, social, sociological and cosmological contexts.

At the surface (linguistic) layer, Solomon reactivates his graphological, morphological, semantic and syntactic competences to write verses 4 and 5. Similarly, Solomon's son or Bible readers must reactivate appropriate competencies to decode the meanings in both verses. The writer's graphological style (of using negative structure to precede affirmative one) is an issue of choice among alternatives. It is assumed that he writes to his son according to his flow of thoughts and perhaps, his presumed order of emphasis.

The situational context reflects the "topic of discourse, factors of the physical events, including concrete objects, persons and locations" (Lawal 2012: 155). Solomon understood the possibility of being drawn into a dialogue with a fool. He gave two conditions or reasons that should form the basis for responding to a fool according to his folly in any given circumstances (V4b and 5b). But the whole text centres on instructions and conditions for conversing with a fool. The first instruction is not to reply to a fool for the possibility of playing the second fool (V4), while the other is to reply where and when a fool may be "wise in his own conceit" (V5). Solomon's son has the responsibility of studying the two contexts and complying appropriately. To do this, his son should possess the background information of the two situations to discover his (Solomon's) intentions, and that of the fool, to draw inferences that will assist in responding to a fool appropriately.

Also relevant in this aspect is the application of one of the four maxims of Grice (1975) known as the Co-operative Principle (CP). The "manner" (fourth maxim) in which an utterance is made is important if participants must avoid ambiguity, must be brief and orderly; anything to the contrary should be seen as lacking "manner". Where a fool displays a lack of "manner", making a contribution in similar manner may amount to playing the second fool. But if a reply in the "manner" a fool speaks is appropriate to counter self-deceit, it should be given (V5). The maxim can assist in establishing the appropriate realisations of Vs 4 and 5 in separate contexts, thereby ruling out possible contradictions.

At the psychological context, the writer of our text resents and hates foolishness and wants his son to handle a fool accordingly. In V4, the author detests a response to a fool that will make his son replicate the ranting of the fool. But as shown in V5, the writer abhors a situation where the fool will go without being replied to if he (the fool) feels "fulfilled".

Father-son-fool relationship on the one hand, and author-Bible user-fool relationship on the other, characterise the social contexts of the text. The instructions in Vs 4 and 5 were primarily directed to Solomon's son; they are now for the benefit of all 
Bible users.

Sociologically, the historical and socio-cultural settings of the text are embedded in the history of the life and times of Solomon. He had a track record of wisdom (1 Kings 29-34). He observed the universe and wrote on several issues of life. As a wise man, he observed the fool and knew his boastings, railings and arrogance. Solomon was well acquainted with the attitude, moods and beliefs of a fool. It would be unrealistic to snub the fool always. Solomon then instructed his son to shun a fool when necessary, and reply to him when appropriate, leaving to his son the responsibility for deciding the time and location to determine the appropriateness of the actions.

The world-view of Solomon, his son, the fool and subsequently all Bible users constitute the context upon which the cosmological factor is built. All over the world, people speak either wisely or foolishly. When people express themselves wisely, precepts are laid and such are models for emulation.

In contrast, a foolish expression receives condemnation, especially by the wise or those who can discern appropriately. Vs $4 \mathrm{~b}$ and $5 \mathrm{~b}$ are two possible effects of life encounters. These effects inform the instructions in $4 \mathrm{a}$ and $5 \mathrm{a}$ respectively. In other words, the world-view of Solomon, his son and Bible users about "the fool" goes a long way to determine the appropriateness of complying with the instructions in our text.

\section{Conclusion}

Resolving an overt contradiction of this sort involves a complex interrelatedness and somewhat intrinsic interplay of language at stylistic, semantic and pragmatic levels. The puzzle that confronts an effort at proffering resolution to the two contradictory verses emerges partly from their paradigmatic sequencing. Hence reconciling the verses goes beyond linguistic and semantic postulations. Pragmatic clues which provide useful background information on the speaker, hearer, topic, place and time of discourse including other contextual factors have simultaneously facilitated the inferences or presuppositions that have been drawn from the intentions of the text writer. Since ordinary sense reveals that it is impossible for a single agent to comply with opposing instructions at the same time, the pragmatic challenges posed by our text have been tackled decisively.

If there was any justification for the flow of thought the author of our text displayed in sequencing his statements or sentences in deviant with regard to grammatical rules, it was the stylistic premise. As revealed in the text, the author couched his utterances by leaning on the good anchor offered by language variation. While leaving his addressees to the task of deciphering his speech through semantic and pragmatic presuppositions, his stylistic competence gave him the leverage of engaging the features of sentence variation, scheme of balance, negative insertion, 
alliteration, repetition, etc. to perform the illocutionary functions of advising and warning his son, and subsequently, to all the users of the Bible.

Importantly too, the issue of "appropriateness" rang throughout the framework of our analysis suggesting the crucial nature of the concept in the study. It avails us a great advantage of situating verses 4 and 5 in terms of their appropriate realisations per time, location and person. In other words, the theory allows the explication of where and when to reply to a fool or to restrain oneself. Herein lays the crux of the needed reconciliation of the two verses that make up our text.

\section{References}

Adeniji, A. \& Osunbade, N. (2014) "Pragmatic Functions of Tradition-Motivated Discourses in Ahmed Yerima's Ajagunmale" in International Journal of English and Linguistics Research. Vol.2, No 2. 1-14.

Adegbija, E.E. (1982) "Speech Act Analysis of Consumer Advertisement" unpublished Ph.D. Thesis. Indiana University, Bloomington.

Adegbija, E.E. (1985) "Semantics in English as a Second Language (ESL)" in Defining English as a Second Language. (ed.) Adebisi Afolayan, Ife: University of Ife, ESL series: 259 $-269$.

Adegbija, E.E. (1988) "My friend where is Anini?: Decoding the meaning of an utterance" in Journal of Pragmatics, 12 (2): 151 - 160.

Adeyanju. D. (1998) "The Sermon on the Mount: A Stylistic Analysis" in Centrepoint: A Journal of Intellectual. Scientific and Cultural Interest (ed.) Sola Babatunde, Ilorin: University of Ilorin Press. 95 - 115.

Allan, Keith (1986) Linguistic Meaning. Vol. 2 New York: Routledge and Kegan Paul Plc.

Ajileye, M.K. and S.S. Ajileye (2012) "Pragma Sociolinguistic Features of Yoruba Nicknames" in Stylistics in Theory and Practice (ed.) Adebayo Lawal, Ilorin Jether Press: 195 - 204.

Austin, J.H. (1962) How to Do Things with Words Cambridge, M.A. Howard University Press.

Bach, K. and R. Harnish (1979) Linguistic communication and Speech Acts Cambridge, M.A.: MIT Press.

Babatunde, J.A. (1988) "The Psalms as Poetry: A Stylistic Analysis of Psalm 119" Unpublished M.A. Thesis Unilorin.

Budge, E. A. (1922) "The Precepts of Life by Amen-em-Apt, the son of Ka-Nekht" Recueil d'etudes egyptologiques dediees a la memoire de Jean-Francois Champollion a l'occasion du centenaire de la letter a M. Dacier relative a l'alpabet des hieroglyphs phonetiques. Paris: E. Champion. 431-446.

Cross, F.L. (1974) The Oxford Dictionary of the Christian Church London: Oxford University Press. 
Ducrot, O. and Todorov, (1972) Encyclopaedic Dictionary of the Science of Language. London and New York: Routledge.

Emerton, J. A. (2001) "The Teaching Amenemope and Proverbs XXII 17-XXIV 22: Further Reflections on a Long-standing Problem" Vetus Testamentum 51 431-465.

Erman, A. (1924) "Eine agyptische Quelle der Spruche Salomos", Sitzungsberichte der Akademie der Wissenschaften 15 86-93.

Grice, H.P. (1975). "Logic and Conversation". in P. Cole and Morgan J. (eds.) Syntax and Semantics Vol.3, New York: Academic Press: 46-58.

House, W.H. and K.M. Durham (1992) Living Wisely in a Foolish World: A Contemporary Look at the Wisdom of Proverbs Lagos: Kregal Publications.

Lakoff, R. (1990). Talking Power: The Politics of Language. New York: Basic Books.

Lawal A. Bade, A. and Raji, W. (1997) "A Pragmatic study of selected pairs of Yoruba proverbs" in Journal of Pragmatics. 27,635 - 652.

Lawal (2012). "Pragmatic in stylistics: A speech Acts Analysis of Soyinka' s "Telephone Conversation" in Stylistics in Theory and Practice (ed.) Adebayo Lawal, Ilorin: Jether Press: 150-173.

Levin, S.R. (1977) The Semantics of Metaphor. London: The John Hopkins University Press.

Leech G. and J. Thomas (1990) "Language Meaning and Context: Pragmatics" in All Encyclopedia of Language (ed.) Collinge, N.L, London: Routledge: 173-201.

Oladosu, A.G.A.S. (2012) "A stylistic Analysis of the Quranic Verse of the Throne" in Adebayo Lawal (ed.) Stylistics in Theory and Practice Ilorin: Jether Press: 217 - 230.

Olajide, B.S. (2012) "Style in scientific prose: A Case Study in ESL context" in Adebayo Lawal (ed.) Stylistics in Theory and Practice llorin: Jether Press: 93 - 105.

Pang, P. (2014) Comparison of the Theologies of Proverbs 22:17 to Proverbs 24:22 and Amenemope. https://www.scribd.com/doc/17820288/Comparison-of-Prov-andAmenemope. Retrieved, $14^{\text {th }}$ Nov. 2016.

Ruffle, J. (1995) "The Teaching of Amenemope and its Connexion with the Book of Proverbs" in Roy Zuck, (ed.) Learning from the Sages; Studies on the Book of Proverbs Baker: Books: 293-331.

Searle, J.R. (1974) Towards a Linguistics Theory of Speech Acts. New York: Academic Press.

Shupak, N. (2005) "The Instruction of Amenemope and Proverbs 22:17-24:22 from the perspective of contemporary Research" in R.L. Trokel, K.G. Friebel and D.R. Magary (eds.) Seeking out the Wisdom of the Ancients: Essays Offered to honour Michael V. Fox on the occasion of his Sixty-fifth Birthday. Eisenbrauns: Eisenbrauns Press. 203217.

Stalnaker, R. (1974) "Pragmatic Presuppositions" in M. Munitz \& P. Unger (Eds.) Semantics and philosophy. New York: New York University Press. 197-213.

The Amplified Bible (1987) Grand Rapids, U.S.A: The Zondervan Corporation and the Lockman Foundation. 
The Holy Bible: Authorised King James Version with Dictionary and Concordance (2003) Lagos: Shalom Publishers.

Whybray, R. N. (1995) The book of Proverbs: A Survey of Modern Study Brill: Brill Press

Wikipedia (2016) Instruction of Amenemope

https://en.wikipedia.org/wiki/Instruction_of_Amenemope Retrieved, $10^{\text {th }}$ Dec, 2016.

Wilson, J. (1951) The Culture of Ancient Egypt. Chicago: University of Chicago Press.

Zavada, J. (2016) christianity.about.com/od/oldtestamentbooks/a/Books-of-Proverbs.htm Retrieved, $10^{\text {th }}$ December 2016. 